\title{
Physico-Chemical Properties of Sweet Orange Growing Soils of YSR District in Andhra Pradesh, India
}

\section{A. Ramanjaneya Reddy ${ }^{*}$, V. Munaswamy, K. Venkaiah, P. Venkataram Muni Reddy, B. Ravindra Reddy and P. Sudhakar}

\author{
S. V. Agricultural College, Acharya N.G. Ranga Agricultural University, \\ Tirupati, Andhra Pradesh - 517502, India \\ *Corresponding author
}

\section{A B S T R A C T}

An investigation was carried out to study the soil physico-chemical properties of the sweet orange orchards in YSR district of Andhra Pradesh. To prosecute this

Keywords

Sweet orange, $\mathrm{pH}, \mathrm{EC}, \mathrm{OC}$, $\mathrm{CEC}, \mathrm{CaCO}_{3}$, YSR district.

Article Info

Accepted:

21 June 2017

Available Online:

10 August 2017 investigation, fifty sweet orange orchards aged between 12 to 13 years were selected and soil samples were collected from these orchards at $0-30 \mathrm{~cm}$ and 30-60 $\mathrm{cm}$ depth. Soil reaction of study area varied widely. Majority of the surface soils samples $(72 \%)$ were mildly alkaline, but at $30-60 \mathrm{~cm}$ depth $48 \%$ were strongly alkaline, $38 \%$ were moderately alkaline and $14 \%$ were mildly alkaline in $\mathrm{pH}$. All the orchards were non-saline in nature. The study area soils were low in organic carbon at surface and sub-surface and decreased with increasing depth. About $70 \%$ of surface samples were moderately calcareous, $24 \%$ were non-calcareous and $6 \%$ were strongly calcareous, but in sub-surface, $74 \%$ were strongly calcareous, $24 \%$ were moderately calcareous and $6 \%$ were non-calcareous. The cation exchange capacity of the surface soils ranged from 24.02 to 64.74 cmol $\left(\mathrm{p}^{+}\right) \mathrm{kg}^{-1}$, with a mean value of $43.84 \mathrm{cmol}\left(\mathrm{p}^{+}\right) \mathrm{kg}^{-1}$ and the sub-surface soils varied from 8.74 to $57.69 \mathrm{cmol}\left(\mathrm{p}^{+}\right) \mathrm{kg}^{-1}$, with a mean value of $38.59 \mathrm{cmol}\left(\mathrm{p}^{+}\right) \mathrm{kg}^{-1}$.

\section{Introduction}

Sweet orange (Citrus sinensis (L.) Osbeck) is one of the most important commercial citrus cultivars of India having significant nutritional source for human health as they contain more of minerals and vitamins (Gallasch et al., 1984; Breeling, 1971).

Most of the fruits are consumed as fresh, while some portion is used in the form of squashes, juices and drinks. Sweet orange fruits form an essential commercial commodity for several industries and possess immense economic value. In India, sweet oranges are grown mainly in the states of Maharashtra, Andhra Pradesh, Punjab, Karnataka and parts of North - East region with an area of 2.78 lakh hectares and 45.26 lakh tones (Horticultural Statistics at a Glance, 2015).

In Andhra Pradesh, the chief sweet orange production areas are Prakasam, YSR, Ananthapur and SPSR Nellore districts with an area of nearly 0.94 lakh ha and production 
of 13.16 lakh tonnes during 2014-15 (Horticultural Statistics at a Glance, 2015). In YSR district, area under sweet orange is 0.11 lakh ha with production of 1.54 lakh $\mathrm{Mt}$ (CPO, YSR district, 2015).

In YSR district sweet orange is cultivating in a variety of soils ranging from red loamy sands/sandy loams to black clay loams/sandy clay loams under semi-arid monsoonic climate with distinct summer, winter and rainy seasons with mean annual temperature of $27-35^{\circ} \mathrm{C}$ and rainfall of $700-800 \mathrm{~mm}$ (Fig. 1 ), but the information regarding to their physico-chemical properties is meager, hence the present investigation was taken up.

\section{Materials and Methods}

For studying the physico-chemical properties of the sweet orange growing soils of the YSR district, during 2014, fifty sweet orange orchards aged between 12 to 13 years were selected (Fig. 2) in different mandals and in each orchard, two pits were dug at random and composite soil samples were separately collected at two depths viz., $0-30$ and $30-$ $60 \mathrm{~cm}$ with geo reference by taking location co-ordinates and processed for analysis.

Soil $\mathrm{pH}$ was determined in 1:2.5 soil water suspension using digital $\mathrm{pH}$ meter (Jackson, 1973). EC was determined in supernatant solution of soil: water suspension (1:2.5) using digital direct read conductivity meter, and expressed in $\mathrm{dS} \mathrm{m}^{-1}$ (Jackson, 1973).

CEC was determined by the ammonium acetate displacement method (Bower et al., 1952). The free calcium carbonate content of the soil was determined by treating the soil with a known volume of standard $\mathrm{HCl}$ and back titrating the unused acid with standard alkali using bromothymol blue as an indicator (Piper, 1968). Organic carbon was determined by the method given by Walkley and Black wet oxidation (1934). Results were analyzed in SPSS 20.0 using Pearson correlation coefficient matrix to know the significant variations among the soil physico-chemical properties. Range, mean and standard deviation were calculated using Microsoft Excel (Microsoft, WA, USA) spread sheet.

\section{Results and Discussion}

\section{Soil pH}

From the data presented in the table 1 and depicted in figure 3 , the $\mathrm{pH}$ of the soils samples ranged from 7.53 to 8.62 and 7.62 to 9.20 at $0-30 \mathrm{~cm}$ and $30-60 \mathrm{~cm}$, respectively. Out of these samples, $72 \%$ of the samples were mildly alkaline, $16 \%$ were moderately alkaline and $12 \%$ were strongly alkaline at 0 $30 \mathrm{~cm}$ and at 30-60 cm, 48\% were strongly alkaline, $38 \%$ were moderately alkaline and $14 \%$ were mildly alkaline in $\mathrm{pH}$ (Fig. 4).

The soils of sweet orange orchards of study area indicated that $\mathrm{pH}$ of the surface soil (0$30 \mathrm{~cm}$ ) was low as compared to that of subsurface soils $(30-60 \mathrm{~cm})$. Similar results were reported by Yasmin et al., (2015) and Surwase et al., (2016).

The lower $\mathrm{pH}$ of surface soil might be due to the presence of more amount of organic matter, and release of organic acids during its decomposition (Chandrasekhara Reddy and Narasimha Rao, 1990).

Citrus was performed well in soils at $\mathrm{pH}$ range of 6.5 to 9.0 (Wander, 1952) and also at a range of 5.5 to 7.5 (Chapman (1960).

\section{Electrical conductivity (EC)}

The electrical conductivity of the soil samples varied from 0.14 to $1.18 \mathrm{dS} \mathrm{m}^{-1}$, with a mean value of $0.35 \mathrm{dS} \mathrm{m}^{-1}$ at $0-30 \mathrm{~cm}$ and at 30 to $60 \mathrm{~cm}$ it ranged from 0.12 to $0.85 \mathrm{dS} \mathrm{m} \mathrm{m}^{-1}$, with a mean value of $0.32 \mathrm{dS} \mathrm{m}^{-1}$ (Table 1 and Fig. 3). 
Fig.1 Average monthly rainfall and temperature of the study area for 2015 and 2016

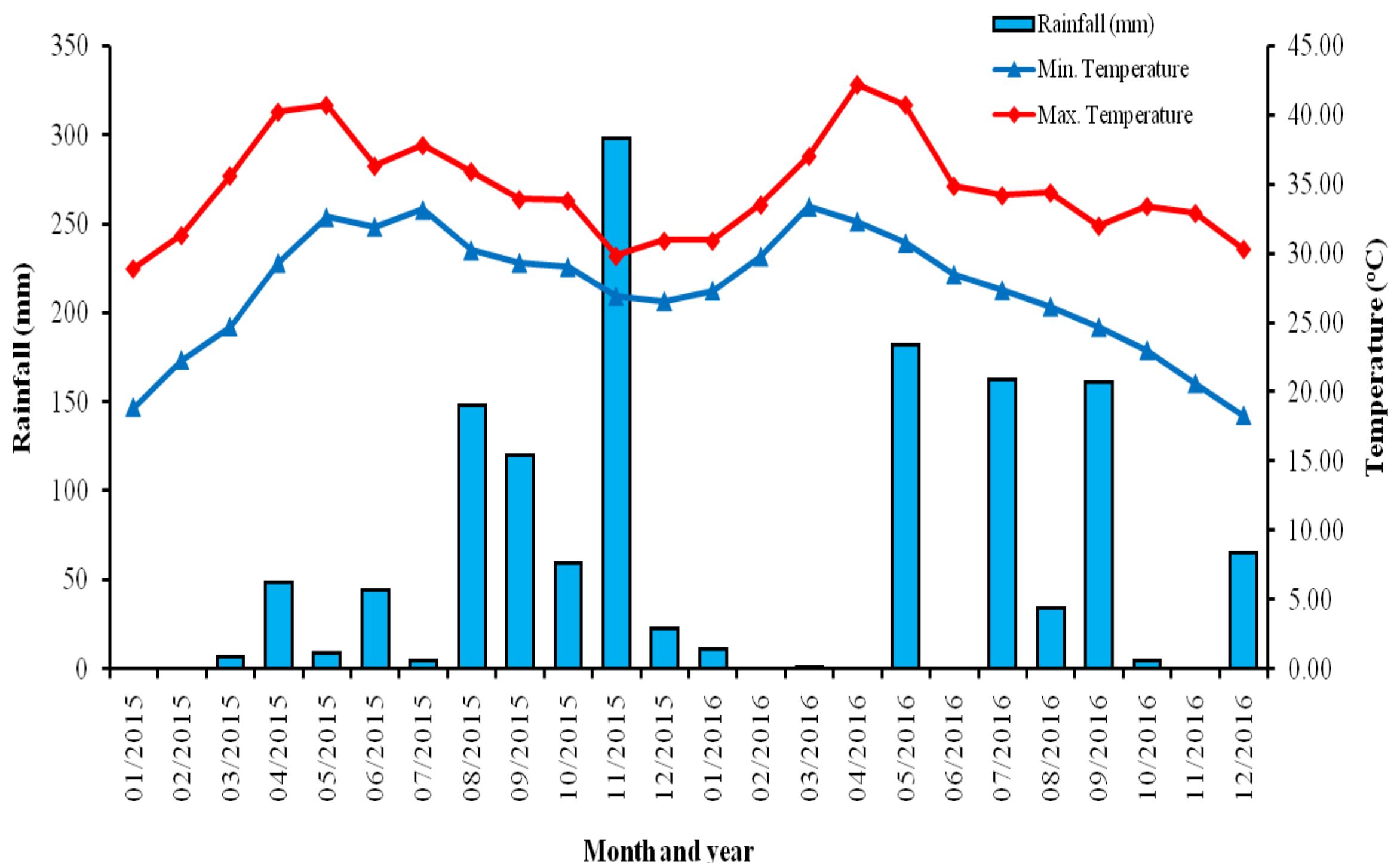


Fig.2 Map showing sampled sites in the different mandals of YSR district

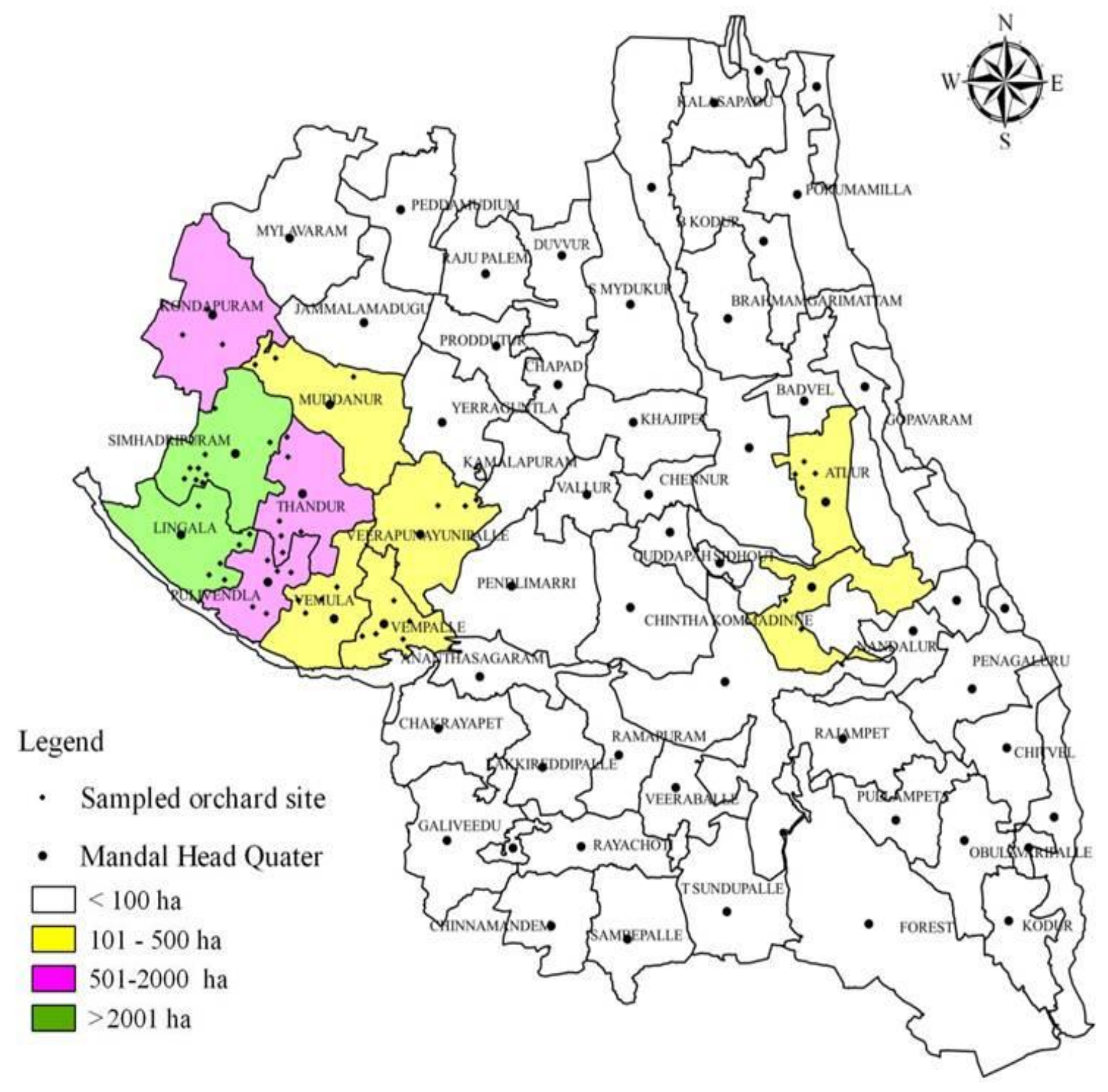


Fig.3 Mean values of soil physico-chemical properties of the sweet orange growing orchards in YSR district

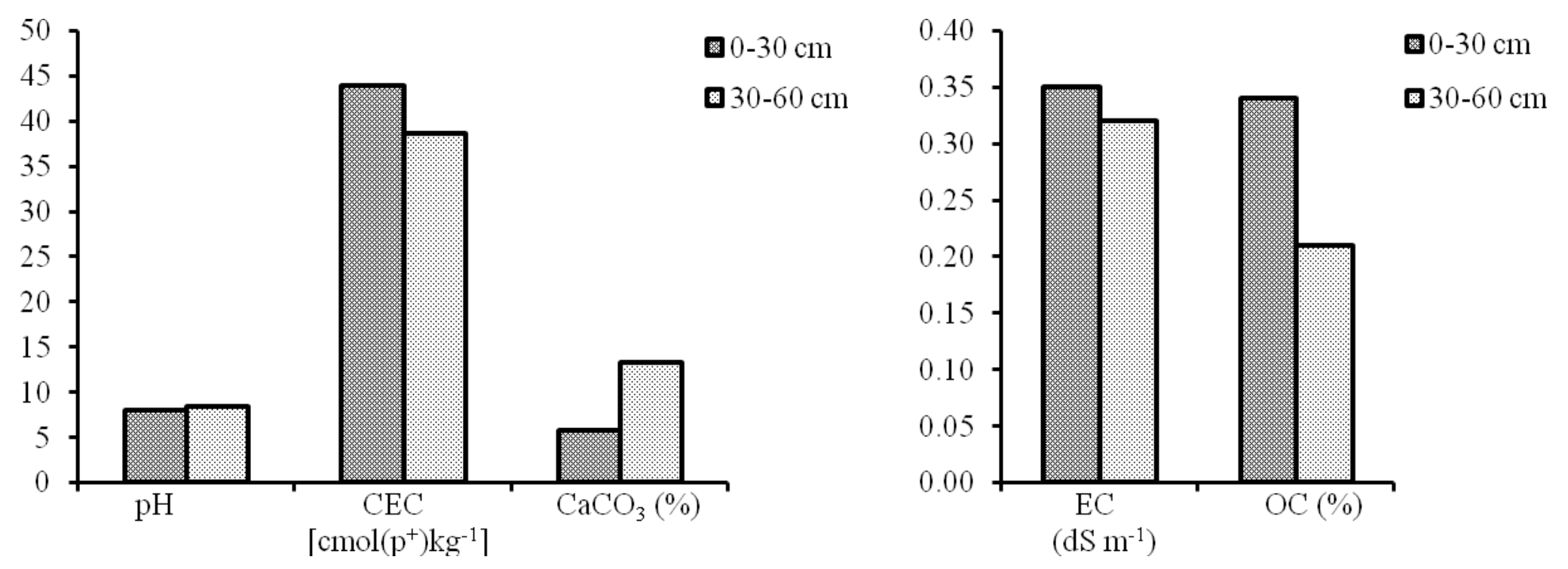

Fig.4 Distribution of $\mathrm{pH}$ in the sweet orange growing soils of the study area

Surface soil $(0-30 \mathrm{~cm})$

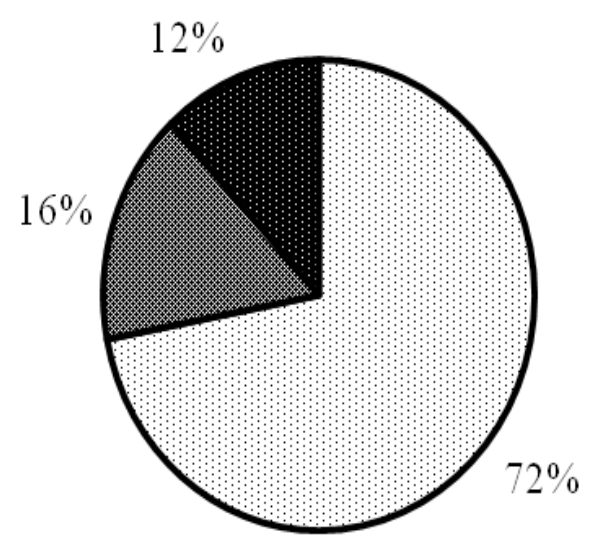

Mildly alkaline Moderately alkaline Strongly alkaline
Sub-surface soil $(30-60 \mathrm{~cm})$

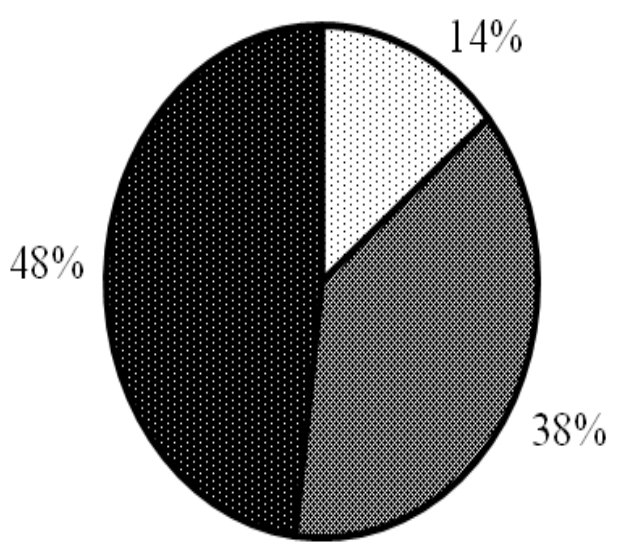

- Mildly alkaline Moderately alkaline $\mathbf{A}$ Strongly alkaline 
Fig.5 Distribution of $\mathrm{CaCO}_{3}$ in the sweet orange growing soils of the study area

Surface soil $(0-30 \mathrm{~cm})$

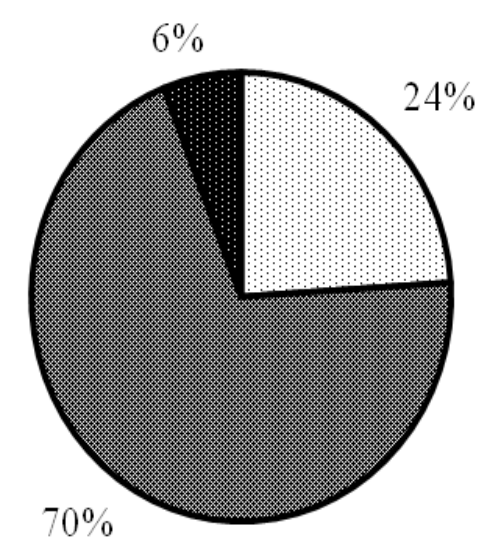

용 Moderately calcareous
Sub-surface soil $(30-60 \mathrm{~cm})$

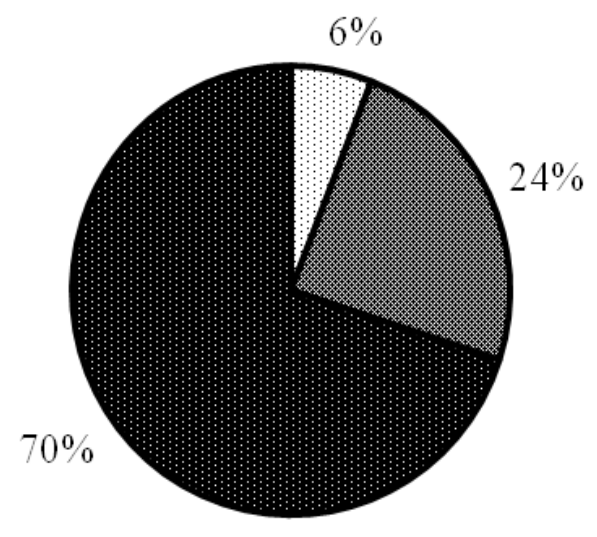

- Non calcareous

Strongly calcareous

- Non calcareous 중 Moderately calcareous

Strongly calcareous

Table.1 Soil physico-chemical properties of the sweet orange growing orchards in YSR district

\begin{tabular}{|c|c|c|c|c|c|c|c|}
\hline \multirow[t]{2}{*}{ Parameter } & \multirow{2}{*}{$\begin{array}{c}\text { Total } \\
\text { samples }\end{array}$} & \multicolumn{3}{|c|}{$0-30 \mathrm{~cm}$} & \multicolumn{3}{|c|}{$30-60 \mathrm{~cm}$} \\
\hline & & Range & Mean & SD & Range & Mean & SD \\
\hline $\mathrm{pH}$ & 50 & $7.53-8.62$ & 7.95 & 0.29 & $7.62-9.20$ & 8.44 & 0.42 \\
\hline $\mathrm{EC}\left(\mathrm{dS} \mathrm{m} \mathrm{m}^{-1}\right)$ & 50 & $0.14-1.18$ & 0.35 & 0.21 & $0.12-0.85$ & 0.32 & 0.20 \\
\hline $\operatorname{CEC}\left(\operatorname{cmol}\left(\mathrm{p}^{+}\right) \mathrm{kg}^{-1}\right)$ & 50 & $24.02-64.74$ & 43.84 & 10.01 & $8.74-57.69$ & 38.59 & 11.42 \\
\hline $\mathrm{CaCO}_{3}(\%)$ & 50 & $1.00-18.50$ & 5.77 & 2.96 & $3.00-36.50$ & 13.27 & 6.13 \\
\hline $\mathrm{OC}(\%)$ & 50 & $0.07-0.50$ & 0.34 & 0.097 & $0.01-0.39$ & 0.21 & 0.09 \\
\hline
\end{tabular}


Slightly high EC was observed at surface than sub-surface, it might be owing to: 1. irrigating the soil with high EC possessing irrigation water. 2. May be due to semi-arid climate of the study area. Under such climatic conditions coupled with drip irrigation - as it supply limited moisture owing to restricted hours of power supply, especially during summer months - the salts move to surface from the deeper layers due to evaporation pull, hence the sweet orange growing surface soils of study area indicates slightly high EC. 3. As the study area reeled under very low rainfall than normal during 2014 - 15, under such conditions use of deep ground water with loads of salts also added the salts to the surface and it increased the EC.

However, all the orchards were non-saline in nature as the mean EC was less than $1.0 \mathrm{dS} \mathrm{m}^{-1}$. Kanwar and Randhawa (1961) proposed that

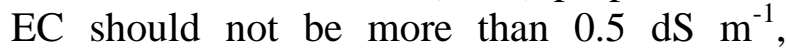
otherwise the growth of citrus could be adversely affected.

\section{Organic carbon (OC)}

The organic carbon content of the sweet orange growing soils of the study area ranged from 0.07 to 0.50 per cent in surface $(0-30$ $\mathrm{cm})$ soils and 0.01 to 0.39 per cent in subsurface $(30-60 \mathrm{~cm})$ soils with average values of 0.34 per cent and 0.21 per cent at surface and sub-surface, respectively (Table 1 and Fig. 3).

The study area soils were low in organic carbon at surface and sub-surface layers. Organic carbon content was high in $0-30 \mathrm{~cm}$ soil than the $30-60 \mathrm{~cm}$ soil, the organic carbon content decreased with increasing depth, it might be due to accumulation of organic carbon was more in surface layer as compared to that of lower layers because organic matter additions were confined to surface layer in sweet orange growing soils. Similar results were reported by Bhargavarami Reddy et al., (2013), Yasmin et al., (2015) and Surwase et al., (2016).

\section{Cation exchange capacity (CEC)}

The cation exchange capacity (CEC) of the surface soils ranged from 24.02 to 64.74 $\operatorname{cmol}\left(\mathrm{p}^{+}\right) \mathrm{kg}^{-1}$, with mean value of 43.84 $\operatorname{cmol}\left(\mathrm{p}^{+}\right) \mathrm{kg}^{-1}$ and the sub-surface soils varied from 8.74 to $57.69 \mathrm{cmol}\left(\mathrm{p}^{+}\right) \mathrm{kg}^{-1}$, with mean value of $38.59 \mathrm{cmol}\left(\mathrm{p}^{+}\right) \mathrm{kg}^{-1}$ (Table 1 and Fig. 3).

Surface soils reported high CEC values than the sub-surface soils, it is established fact that the cation exchange capacity of soil depends upon the amount and nature of the clay and organic matter content. Owing to the high organic matter and significant amount of clay content in the surface soil, the CEC recorded higher values than the sub-surface. Similar results were reported by Singh and Lai (1968), Mohekar (1999) and Yadav and Meena (2009).

\section{Calcium carbonate $\left(\mathrm{CaCO}_{3}\right)$}

The calcium carbonate content of soil showed a varied from 1.00 to 18.50 per cent and 3.00 to 36.50 per cent with mean values of 5.77 per cent and 13.27 per cent in surface and subsurface soils, respectively (Table 1 and Fig. $3)$.

About $24 \%$ of the surface soils were noncalcareous, $70 \%$ were moderately calcareous and $6 \%$ were strongly calcareous, but in subsurface, $6 \%$ were non-calcareous, $24 \%$ were moderately calcareous and $74 \%$ were strongly calcareous (Fig. 5).

The content of calcium carbonate was less in surface soil $(0-30 \mathrm{~cm})$ than in sub-surface soil $(30-60 \mathrm{~cm})$. The increase in calcium carbonate with depth had also been reported 
by Jagdish Prasad et al., (2001), Yasmin et al., (2015) and Surwase et al., (2016). The increase of calcium carbonate in the lower horizon might be due to calcification, leaching of calcium carbonate and inheritance from parent material.

In conclusion, the study area soil reaction varied widely, it ranged from mildly alkaline to strongly alkaline, the soils were non-saline in nature as the EC of these soils was far below $4.0 \mathrm{dS} \mathrm{m}^{-1}$. About $24 \%$ of the surface soils were non-calcareous, $70 \%$ were moderately calcareous and $6 \%$ were strongly calcareous, but in sub-surface, $6 \%$ were noncalcareous, $24 \%$ were moderately calcareous and $74 \%$ were strongly calcareous.

\section{References}

Bhargavarami Reddy, C. H., Guldekar V. D., and Balakrishnan, N. 2013. Influence of soil calcium carbonate on yield and quality of Nagpur mandarin. African Journal of Agricultural Research. 8 (42): 5193-5196.

Bower, C. A., Reitemeir, R. F., and Fireman, M. 1952. Exchangeable cation analysis of saline alkaline soils. Soil Science. 13: 251-261.

Breeling, J. L. 1971. Nutritional guidelines. Journal of the American Dietetic Association. 59: 102-105.

Chandrasekhara Reddy, K., and Narasimha Rao, Y. 1990. Characterization of alluvial soils of Endakuduru village Krishna district A.P. The Andhra Agricultural Journal. 37: 129-135.

Chapman, H. D. 1960. Leaf and soil analysis in citrus orchards - criteria for the diagnosis of nutrient status and guidance of fertilization and soil management. Manual 25, Riverside, University of California. 53.

CPO (Chief Planning Officer). 2015. YSR District statistical database. YSR district, Andhra Pradesh.

Gallasch, P. T., Dalton, G.S., and Ziersch, J. 1984. The use of juice analysis to define fertilizer requirements of citrus. In Heitor W. Studart Montenegro and C. S. Moreira (eds.), Proceedings of International Society of Citriculture. July 15-20, Sao Paulo, Brazil. 2: 140142.

Horticulture Statistics Division, Ministry of Agriculture and Farmers Welfare, Government of India. 2016. Horticultural Statistics at a Glance 2015. Oxford University Press. New Delhi 110001, India. 17.

Jackson, M. L. 1973. Soil Chemical Analysis. Oxford and IBH Publishing House, Bombay. 38.

Jagdish Prasad, M. S., Nagaraju, Rajeev Srivastava, Ray, S. K., and Chandran, P. 2001. Characteristics and classification of some orange growing soils in Nagpur district of Maharashtra. Journal of the Indian Society of Soil Science. 49 (4): 735-739.

Kanwar, J. S., and Randhawa, N. S. 1961. Soil salinity and zinc deficiency the two important causes of chlorosis of citrus in the Punjab. Horticultural Advance (in press).

Mohekar, D. S. 1999. Characterisation of orange (Citrus reticulata Blanco) growing soils of Nagpur district and their suitability evaluation. Land resource management NBSS Publications. 73: 65-66.

Piper, C. S. 1968. Methods of Soil analysis. Hans's publishers, Bombay.

Singh, K. S., and Lai, P. 1968. A note on the effect of organic carbon on the CEC of soil. Annals of Arid zone. 7 (1): 139-141.

Surwase, S. A., Kadu, P. R., and Patil, D.S. 2016. Soil micronutrient status and fruit quality of orange orchards in Kalmeshwar Tahsil, District Nagpur 
(MS). Journal of Global Biosciences. 5: 3523-3533.

Walkley, A., and Black, I. A. 1934. An examination of the Degtjareff method for determining soil organic matter, and a proposed modification of the chromic acid titration method. Soil Science. 37: 29-38.

Wander, I. W. 1952. Soil reaction or $\mathrm{pH}$. California Citrograph. 337:358.

Yadav, R. L., and Meena, M. C. 2009. Available micronutrient status and their relationship with Soil Properties of Degana Soil Series of Rajasthan. Journal of the Indian Society of Soil Science. 57 (1): 90-92.

Yasmin, C., Venkaiah, K., Naidu, M. V. S., Munaswamy, V., Subramanyam, D., and Mohan Naidu, G. 2015. Physicochemical properties of sweet orange growing soils of Anantapur District. Bioinfolet. 12 (3B): $680-682$.

\section{How to cite this article:}

Ramanjaneya Reddy, A.V. Munaswamy, K. Venkaiah, P. Venkataram Muni Reddy, B. Ravindra Reddy and Sudhakar, P. 2017. Physico-Chemical Properties of Sweet Orange Growing Soils of YSR District in Andhra Pradesh. Int.J.Curr.Microbiol.App.Sci. 6(8): 24312439. doi: https://doi.org/10.20546/ijcmas.2017.608.287 